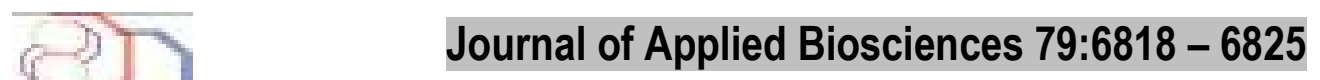

ISSN 1997-5902

\title{
Nutritional diversity of leafy amaranth species grown in Kenya
}

\author{
Esther N. Muriuki ${ }^{1}, 2^{\star}$, Daniel N. Sila ${ }^{1}$, Arnold Onyango ${ }^{1}$ \\ 1 Faculty of Agriculture, Jomo Kenyatta University of Agriculture \& Technology, Nairobi Kenya. \\ 2. School of Health Sciences, Mount Kenya University P.O Box 342 Nairobi, Kenya \\ *Correspondence e-mail: enmuriuki@gmail.com , Mobile No: +254723745113
}

Original submitted in on 22 nd April 2014. Published online at www.m.elewa.org on $31^{\text {st }}$ July 2014. http://dx.doi.org/10.4314/iab.v79i1.9

\begin{abstract}
Objectives: Despite the availability of many species of amaranth in Kenya, there is inadequate information on their nutritional diversity and how they can be best used in mitigation of malnutrition. Hence, this study was aimed at investigating the nutritional diversity of five leafy amaranth species grown in Kenya.

Methodology and results: Amaranth vegetables were harvested 5-6 weeks after planting. They were analyzed for their nutritional and phytochemical content using standard methods. Moisture content was lowest in A.cruentus $(79.29 \pm 1.26 \%)$. A.cruentus had the highest protein $(4.37 \pm 0.02 \%)$. The fat content of $A$.hybridus $(2.53 \pm 0.06 \%)$ and $A$.hypochodriacus $(2.63 \pm 0.11 \%)$ was significantly higher than the other species. The crude fibre content $(3.01 \pm 0.29 \%)$ was similar in all the species. A.dubius had the highest calcium $(336.47 \pm 0.9 \mathrm{mg} / 100 \mathrm{~g})$ and iron $(18.64 \pm 0.23 \mathrm{mg} / 100 \mathrm{~g})$ while A.cruentus was highest in zinc content $(1.67 \pm 0.03 \mathrm{mg} / 100 \mathrm{~g})$. The total phenols content was highest in A.cruentus $(3.59 \pm 0.01 \mathrm{GAE} / 100 \mathrm{mg})$. Catechins were highest in A.cruentus $(7.15 \pm 0.63 \mathrm{CE} / 100 \mathrm{mg})$ while quercetin was highest in A.cruentus (14.28 $\pm 0.86 \mathrm{QE} / 100 \mathrm{mg})$.

Conclusion and application of results: More than $50 \%$ of the Kenyan population live below the poverty line and lack access to adequate food. The food available food is of poor nutritional value, this causes malnutrition and other nutritional disorders. There is therefore a need to identify nutrient-rich foods that can be produced inexpensively to meet the nutrient requirements of everyone and especially the vulnerable groups, such as pregnant women, children and the elderly. Amaranth is drought tolerant, grows fast and is easily cultivated. This study indicates that the Amaranth species found in Kenya are a good source of key nutrients, which can be used in mitigation of malnutrition. A.dubius is a superior source of calcium and iron and can help curb the micronutrient deficiencies in Kenya, while A.cruentus is a superior source of protein and phytochemicals which are important in reducing the risk of chronic diseases which are so rampant in Kenya today.
\end{abstract}

Key words: A. dubius, A. hybridus and A. cruentus, A. albus and A. hypochondriacus. Nutrients.

\section{INTRODUCTION}

Amaranth is the collective name for the genus Amaranthus (family Amaranthaceae). It is one of the oldest food crops in the world with evidence of cultivation dating back to over 6000 years in Puebla,
Mexico (Itúrbide and Gispert, 1994). The genus Amaranthus has received considerable attention in many countries because of the high nutritional value of some species that are important sources of food, 
as either vegetable or grain (Srivastava, 2011). The grain and vegetable types can be differentiated but often both the grain and leaves are utilized (Saunders and Becker, 1984; Tucker, 1986). Amaranthus species can produce a crop of edible leaves within two weeks for up to six months
(National research council of Washington 1984). Among the species commonly found in Kenya are, A. dubius and Amaranthus hybridus, which is grown as vegetables while Amaranthus Cruentus is grown as grain and $A$. hypochondriacus is dual purpose.(Figure $1 \mathrm{a}, \mathrm{b}, \mathrm{c}$, and d)

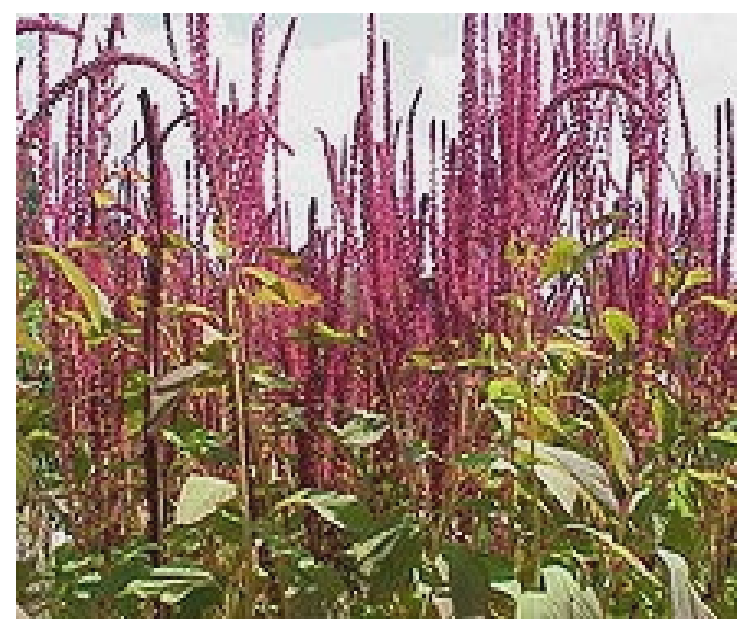

Figure 1 (a) A.cruentus

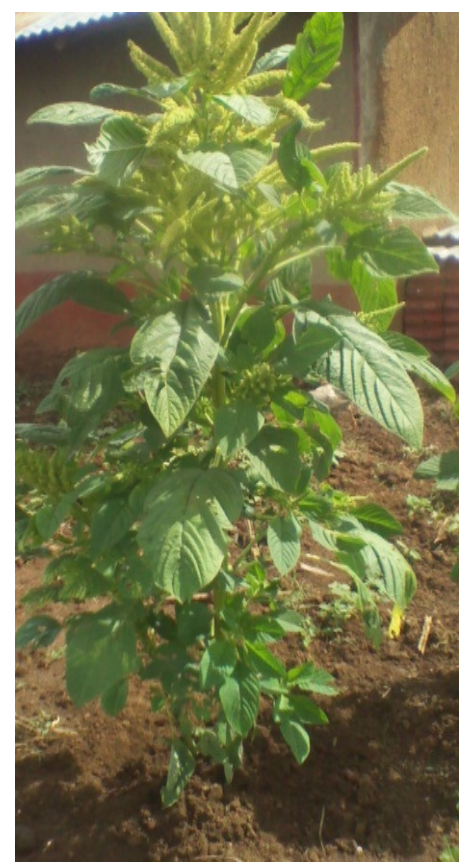

(c) A.albus

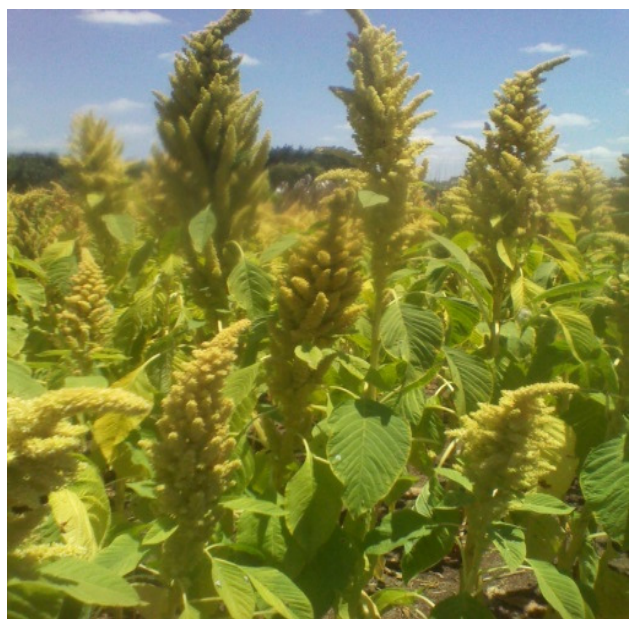

(b) A.hypochondriacus

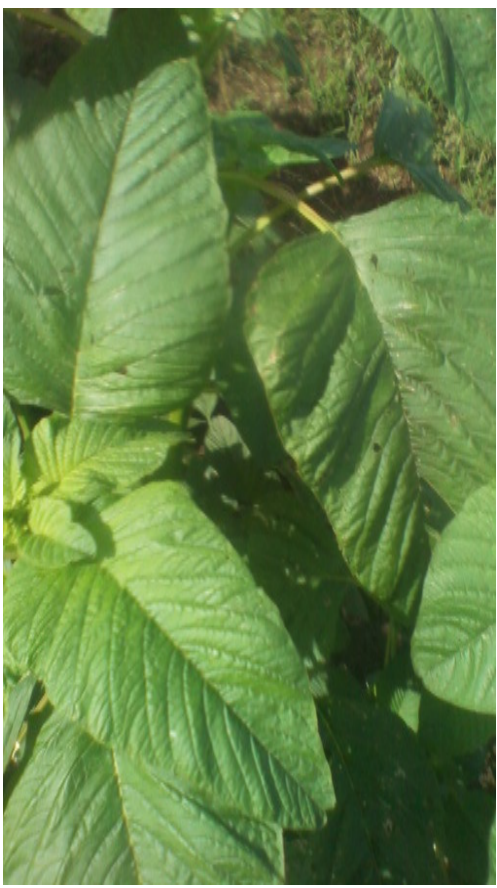

d) A.dubius 
Amaranth is highly nutritious, cheap to produce and easily adapts to the environment in which it grows (Wambugu, and Muthamia, 2009). It is drought tolerant and has the earliest maturity period in the cereal class ranging between 45 days to 75 days (Jacob 2005). Therefore, increased production of this crop has the potential to contribute to improved food and nutritional security among vulnerable communities. In Kenyan rural areas, amaranth is largely grown by women, thus providing them with a degree of financial independence and better nutrition (IPGRI, 2003). The volumes of production and trade in vegetable amaranth have increased over the last

\section{MATERIALS AND METHODS}

Research design: An experimental plot of about $1 / 4$ acre was acquired at the Jomo Kenyatta University Agriculture and Technology research farm for planting the vegetables. The seeds of the five amaranth species were planted in blocks of $3 \mathrm{~m}$ by $3 \mathrm{~m}$ and spacing of $30 \mathrm{~cm}$ by $10 \mathrm{~cm}$ between vegetables. No artificial fertilizers were used but farm yard manure was applied at planting. Irrigation was undertaken every 3 days using overhead sprinklers while weeding was carried out weekly. Leaves of each of the vegetables were harvested between 5-6 weeks after planting. They were then cleaned by removing all adhering dirt, fibrous leaves and damaged parts.

Proximate composition: Moisture was determined according to AOAC methods specification 95046 , method 925.10-32.10.03 (AOAC, 1995). Results were reported on the wet weight basis. Protein was determined using the semi-micro kjeldahl method, specification 950.46, method 20.87-37.1.22 (AOAC, 1995). Fat Determination was done using the soxhlet method 920.85-32.1.13, (AOAC, 1995). Crude fibre was determined according to method 920.86.32.1.15 (AOAC, 1995). Ash content was determined by incinerating in a muffle furnace (AOAC, 1995) method 923.03-32.1.05. The atomic absorption spectrophotometer (AAS) method was applied to determine iron calcium and zinc content (AOAC, 1995).

\section{Determination of phytochemicals}

Solvent extraction: Initial ethanol extraction was applied for the fresh vegetables. Fifty grams of the fresh leaves were put in a flask was covered with $500 \mathrm{ml}$ methanol and allowed to stand for $48-72 \mathrm{~h}$. It was then filtered through Whatman filter paper No. 1 and distilled using rotary few years in response to the growing urban vegetable demand (Onyango and Imungi, 2007). Today, vegetable amaranth is found in many supermarkets and green groceries in the urban centres. More than $90 \%$ of the supply to these outlets is from farms that are within the environs of the urban centres (Onyango et al, 2008). There are many cultivars of leafy amaranth in cultivation in Kenya but it is not known which of these has the highest nutritional value. As such it is of interest to map out the nutritional diversity of the different species of amaranth found in Kenya as a criterion for deciding its production, consumption and marketing.

evaporator (Bibby Sterilin Ltd, RE 100B, UK) at $60^{\circ} \mathrm{C}$ until ethanol- free liquid was obtained. The resulting extracts were then subsequently labelled as ethanol extracts and preserved at $5^{\circ} \mathrm{C}$ in airtight bottles until further use (Alanis et al., 2005).

Total phenolic assay: Total phenolic content in the vegetables was estimated spectrophotometrically using Folin Ciocalteu reagent, as described by Spanos and Wrolstad (1990) with slight modification, using Gallic acid as a standard. One millilitre of ethanolic extract was transferred into a test tube and mixed with $5 \mathrm{ml}$ of distilled water. To each sample $0.5 \mathrm{ml}$ of $0.2 \mathrm{~N}(\mathrm{v} / \mathrm{v})$ Folin-Ciocalteu reagent was added and mixed. After $5 \mathrm{~min}, 1.5 \mathrm{ml}$ of $5 \%$ $\mathrm{Na}_{2} \mathrm{CO}_{3}$ was added to the reaction mixture and allowed to stand for $60 \mathrm{~min}$. The absorbance was read at $765 \mathrm{~nm}$. The absorbance values were converted to total phenolic and were expressed in milligrams equivalents of Gallic acid per grams of the sample. Standard curves were established using various concentrations of Gallic acid in $95 \%$ ethanol.

Catechin and Quercetin Assay: The calorimetric aluminium chloride method was used. One (1) $\mathrm{ml}$ of ethanolic extract was added to $4 \mathrm{ml}$ of water and $0.3 \mathrm{ml}$ of $5 \%$ sodium nitrite was then added. After 2 minutes $0.3 \mathrm{ml}$ of $10 \%$ aluminium chloride was added and allowed to stand for 6 minutes, $2 \mathrm{ml}$ of $1 \mathrm{M}$ sodium hydroxide was then added and the solution topped up with $10 \mathrm{ml}$ distilled water. The absorbance was read at $415 \mathrm{~nm}$ against catechin and quercitin standards.

Data Analysis: The data obtained was subjected to one way analysis of variance (ANOVA), SAS statistical package. Significantly different means were separated by 
Duncan's multiple range tests. Results were given at $5 \%$

\section{RESULTS AND DISCUSSION}

Proximate composition: The proximate composition of the five species is shown in Table 1. There were significant inter-species differences in moisture, protein, ash, and fat content contents but not in the crude fibre. All the species had considerably high moisture content ranging between (79.29-82.52\%). A cruentus exhibited significantly lower moisture content and significantly higher protein content than the other species. Protein values ranged from (2.3-4.37\%). Asibey and Tayie (1999). (reported lower values of $2.1 \%$ in Amaranth incarvutus, while Kwenin and Dzomeku (2011), found similar values $(4.46 \%)$ in A.cruentus. The protein content of $A$. cruentus $(4.37 \%)$ is considerably higher than other vegetables consumed in Kenya. For example, Hanif et al. (2006) found crude protein content ranging from $0.9 \%$ to $2.1 \%$ in cauliflower, carrot, cabbage, lettuce, spinach. Uusiki et al (2010) reported 3\% protein in pumpkin leaves. Hence, amaranth vegetables can be an important source of dietary protein especially to the poor who cannot afford animal protein. The fat content of $A$. significance levels.

hybridus $(2.53 \pm 0 . \%)$ and $A$. hypochodriacus $(2.63 \pm 0.11 \%)$ was significantly higher than the other species, but these values are lower compared to the fat content reported for black nightshade $(8 \mathrm{mg} / 100 \mathrm{~g})$ by Gqaza et al 2013. The ash content ranged from (1.213.3.0\%), which is comparable to that of Amaranth incarvutus (1.4\%) as documented by Asibey and Tayie (1999). The crude fibre content ranged from 2.31 to 3.01 , and is higher than the figure that was reported by Funke, (2011) of $(0.77 \%)$. However, these values are in the same range as those of Corchorus olitorius (Jute mallow), $(2.10 \%)$ and C. ochroleuca (Slender leaf) (1.2\%). (Mibei, 2011).Children, adults, pregnant and lactating mothers require 19-25, 21-38, 28 and $29 \mathrm{~g}$, of dietary fibre respectively (National academy of sciences, 2001). Consumption of 100 grams of fresh amaranth could contribute $15 \%$ of the recommended daily allowance. Crude fibre is important in reducing the risk of colon cancer, constipation, diabetes and reducing absorption of cholesterol (Ishida et al., 2000).

Table 1: Proximate composition of the amaranth vegetables (\%)

\begin{tabular}{lccccc}
\hline & A.albus & A.hybridus & A.cruentus & A.dubius & A.hypochondriacus \\
\hline Moisture & $81.2^{\mathrm{a}} \pm 0.45$ & $81.52^{\mathrm{a}} \pm 0.26$ & $79.2^{\mathrm{b}} \pm 1.26$ & $82.53^{\mathrm{a}} \pm 0.16$ & $82^{\mathrm{a}} \pm 4^{\mathrm{a}} \pm 0.60$ \\
Protein & $2.3^{\mathrm{d}} \pm 0.06$ & $3.3^{\mathrm{b}} \pm 0.06$ & $4.37^{\mathrm{a}} \pm 0.02$ & $2.74^{\mathrm{c}} \pm 0.06$ & $3.34^{\mathrm{b}} \pm 0.09$ \\
Fat & $1.5^{\mathrm{b}} \pm 0.03$ & $2.53^{\mathrm{a}} \pm 0.06$ & $1.62^{\mathrm{b}} \pm 0.03$ & $1.88^{\mathrm{b}} \pm 0.07$ & $2.63^{\mathrm{a}} \pm 0.11$ \\
Ash & $2.35^{\mathrm{b}} \pm 0.13$ & $2.23^{\mathrm{b}} \pm 0.34$ & $1.52^{\mathrm{c}} \pm 0.02$ & $3.30^{\mathrm{a}} \pm 0.04$ & $1.21^{\mathrm{c}} \pm 0.13$ \\
Crude fibre & $2.3^{\mathrm{a}} \pm 0.23$ & $2.85^{\mathrm{a}} \pm 0.55$ & $3.01^{\mathrm{a}} \pm 0.29$ & $2.53^{\mathrm{a}} \pm 0.17$ & $2.49^{\mathrm{a}} \pm 0.09$ \\
Carbohydrates & $10.11^{\mathrm{a}} \pm 1.00$ & $7.3^{\mathrm{b}} \pm 0.23$ & $10.19^{\mathrm{a}} \pm 0.64$ & $7.02^{\mathrm{b}} \pm 0.12$ & $7.9^{\mathrm{b}} \pm 043$ \\
\hline
\end{tabular}

Values are given as means of three replicates \pm SEM. Means with different small letters within a row are significantly different $(P<0.05)$. SEM= Standard error of the mean

Minerals composition: This study revealed significant inter-species differences in the mineral levels (Table 2). A. dubius was found to have the highest levels of iron $(18.63 \pm 0.23 \quad \mathrm{mg} / 100 \mathrm{~g})$ and calcium $(336.47 \pm 0.99 \mathrm{mg} / 100 \mathrm{~g})$. While A.hypochondriacus recorded the lowest iron and calcium contents of $(9.55 \pm 0.15 \mathrm{mg} / 100 \mathrm{~g})$ and $(131.06 \pm 3.14 \mathrm{mg} / 100 \mathrm{~g})$ respectively. Values of iron obtained in this study agree with findings of Onyango (2010) who reported iron content in A. hypochrondicus as (16 $\pm 3 / \mathrm{mg} 100 \mathrm{~g})$. Raja et al. (1997) reported iron contents of $13.43 \mathrm{mg}$ per $100 \mathrm{~g}$ in amaranth sold in Dar es Salaam, while Srivastava (2011) reported a range of $(12.23-14.55 \mathrm{mg} / 100 \mathrm{~g})$ iron in other Amaranth species the iron contents are high as compared to some vegetables consumed in Kenya. For example, the iron contents of spinach (Spinacia oleracea) is about $1.7 \mathrm{mg}$ per $100 \mathrm{~g}$ edible portion (FAO, 2004) while Hanif et al 2006 documented $1.4 \mathrm{mg} / 100 \mathrm{~g}$ and 
$1.1 \mathrm{mg} / 100 \mathrm{~g}$ of iron in carrot and lettuce respectively. Iron is especially important to women of reproductive age, pregnant women and young children who are vulnerable to iron deficiency anaemia. The daily iron requirements for children range between $7-15 \mathrm{mg} /$ day and women of reproductive age require $15-18 \mathrm{mg} /$ day while pregnant women require $27 \mathrm{mg} /$ day (National academic press 2001). Thus, consumption of $100 \mathrm{~g}$ of amount of amaranth leaves from the species $A$. dubius would meet $100 \%$ of the daily requirements if the iron is highly bioavailable. The levels of zinc ranged from $(1.36-1.67 \mathrm{mg} / 100 \mathrm{~g})$ which is lower than the values obtained by (i) Raja et al. (1997) who reported values of $4.08 \mathrm{mg} / 100 \mathrm{~g}$ for amaranth collected in various markets in Dar es Salaam; and (ii) Onyango (2010), who obtained values of up to $6.3 \mathrm{mg} / 100 \mathrm{~g}$ in $A$. hypochrondiacus sold in various supermarkets in Kenya. However, these values are higher than those recorded by Mibei (2011) in Cleome gynandra (spider plant) $(0.1 \mathrm{mg} / 100 \mathrm{~g})$. Jaarsvelda (2006) also recorded lower values of zinc $0.75 \mathrm{mg} / 100 \mathrm{~g}$ and 0.42 $\mathrm{mg} / 100 \mathrm{~g}$ in Curcurbita muschata (pumpkin leaves) and in Vigna unguiculata (cowpeas leaves) respectively. Since an adult requires $8-13 \mathrm{mg} /$ day of zinc, consumption of $100 \mathrm{~g}$ of amaranth vegetable from A.cruentus species would contribute to $10 \%$ of the daily requirements. Zinc is necessary for a wide range of biochemical, immunological and clinical functions and is present in all body tissues and fluids ( $\mathrm{Ma} \mathrm{G}$ et al 2005). These biochemical functions of zinc are responsible for its unique role for growth and development. A.dubius had the highest calcium content $(336.47 \pm 0.99 \mathrm{mg} / 100 \mathrm{~g})$. Calcium was considerably high in all the five species, compared to other vegetables. For example, Hanif et al (2006) found $76 \mathrm{mg} / 100 \mathrm{~g}$ in spinach and $52 \mathrm{mg} / 100 \mathrm{~g}$ in cabbage, and Mibei (2011) reported a calcium content of $94.1 \mathrm{mg} / 100 \mathrm{~g}$ in spider plant. Calcium is essential for the full activity of many enzymes such as nitric oxide synthase, protein phosphatases, and adenylate kinase and is required as a component of the human diet. Chronic calcium deficiency contributes to a reduction in bone mass and the development of osteoporosis. RDA is $1000 \mathrm{mg} /$ day for adults aged 19-50years (The council for responsible nutrition, 2002). Consumption of 100 grams of amaranth would contribute to $30 \%$ of recommended calcium intake.

Table 2: Mineral composition of the amaranth vegetables in WWB

\begin{tabular}{lccccc}
\hline & A.albus & A.hybridus & A.cruentus & A.dubius & A.hypochondriacus \\
\hline Calcium & $235.19^{\mathrm{b}} \pm 0.89$ & $198.48^{\mathrm{c}} \pm 5.08$ & $222.69^{\mathrm{b}} \pm 1.75$ & $336.47^{\mathrm{a}} \pm 0.99$ & $131.06^{\mathrm{d}} \pm 3.14$ \\
Zinc & $1.40^{\mathrm{a}} \pm 0.03$ & $0.892^{\mathrm{c}} \pm 0.35$ & $1.67^{\mathrm{a}} \pm 0.03$ & $0.60^{\mathrm{c}} \pm 0.05$ & $1.36^{\mathrm{a}} \pm 0.04$ \\
Iron & $11.42^{\mathrm{b}} \pm 0.10$ & $10.57^{\mathrm{c}} \pm 0.06$ & $11.61^{\mathrm{b}} \pm 0.30$ & $18.64^{\mathrm{a}} \pm 0.23$ & $9.55^{\mathrm{d}} \pm 0.15$
\end{tabular}

Values are given as means of three replicates \pm SEM. Means with different small letters within a row are significantly different $(P<0.05)$. SEM $=$ Standard error of the mean

Phytochemical composition: Phytochemicals are bioactive non-nutrient plant compounds in plant foods. Table 3 shows that $A$ cruentus had significantly high levels of all the three phytochemicals compared to all other species, while $A$ hypochrondicus had significantly $(p<0.05)$ low amounts of total phenols and $A$ dubius had lowest quercitin.

Table 3: Phytochemical composition of the amaranth vegetables in GAE, CE, and QE $\mathrm{mg} / 100 \mathrm{~g}$

\begin{tabular}{lccccc}
\hline & A.albus & A.cruentus & A.dubius & A.hybridus & A.hypochondriacus \\
\hline Total phenols (TP) & $2.24^{\mathrm{b}} \pm 0.07$ & $3.59^{\mathrm{a}} \pm 0.01$ & $2.22^{\mathrm{b}} \pm 0.19$ & $2.77^{\mathrm{a}} \pm 0.02$ & $1.68^{\mathrm{c}} \pm 0.001$ \\
Catechins & $5.55^{\mathrm{a}} \pm 0.18$ & $7.15^{\mathrm{a}} \pm 0.63$ & $3.75^{\mathrm{b}} \pm 0.39$ & $6.05^{\mathrm{a}} \pm 0.10$ & $3.63^{\mathrm{b}} \pm 0.2$ \\
Quercetin & $12.55^{\mathrm{a}} \pm 1.04$ & $14.28^{\mathrm{a}} \pm 0.86$ & $4.69^{\mathrm{b}} \pm 0.45$ & $13.76^{\mathrm{a}} \pm 1.16$ & $6.5^{\mathrm{b}} \pm 0.71$ \\
\hline
\end{tabular}

Values are given as means of three replicates \pm SEM. Means with different small letters within a row are significantly different $(P<0.05)$. SEM= Standard error of the mean, $\mathrm{GAE}=$ Gallic acid equivalent, $\mathrm{CE}=$ Catechin equivalent, $\mathrm{QE}=$ Quercetin equivalent 
Total phenolics (TP) ranged from 1.68 3.59GAEmg/100g.A.hypochondriacus had the lowest total phenols $(1.68 \pm 0.001 \mathrm{mg} / 100 \mathrm{~g})$. The values of total phenols in $A$ hybridus were much lower than those reported by Nana et al (2000) who indicated a value of $8.30 \pm 0.52 \mathrm{GAE} / 100 \mathrm{~g}$ in $A$. hybridus. The quercitin contents of A.cruentus $(14.28 \pm 0.86 \mathrm{QE} / 100 \mathrm{~g})$ and A.hybridus (13.76 \pm 1.16 (QEmg/100g) were higher than those reported for these species $(2.90 \pm 0.25 \mathrm{QEmg} / 100 \mathrm{~g}$ and $4.33 \pm 0.27 \mathrm{QE} / 100 \mathrm{~g}$ respectively) by Nana et al (2000). These differences may be due to differences in soils, climate or environmental stresses. Nevertheless, amaranth contains higher quercetin than some commonly consumed vegetables. For example Bhagwat et al (2011),

\section{CONCLUSION}

This study indicates that the Amaranth species found in Kenya are a good source of key nutrients. The species exhibited significant differences in their nutrient composition. According to this study, A. dubius is the most preferred species in terms of its nutrient composition, whereas A.cruentus is the second most preferred $A$. cruentus had the highest protein. A.dubius is not only a superior source of iron and calcium than the other amaranth species but is also superior to other green vegetables grown in Kenya. A. cruentus is a good source of zinc. These species could serve as potential sources of nutrients for alleviation of problems associated with micronutrient deficiency in Kenya. A.cruentus had the

\section{ACKNOWLEDGEMENT}

I wish to appreciate and express my sincere gratitude to Australian Government (AusAID) through, A BecAhubCSIRO initiative on Food and Nutrition Security for

\section{REFERENCES}

Alanis, A.D., Glazada, F., Cervantes, J.A., Tarres, J. and Ceballas, G.M. (2005) Antibacterial properties of some plants used in Mexican traditional medicine for the treatment of gastrointestinal disorders. Journal of Ethnopharmacology. 100(1-2): 153-157.

Asibey-Berko, E. and F.A.K. Tayie. (1999). Proximate analysis of some underutilized Ghanaian Vegetables. Ghana J. Sci., 39: 91-92.

AOAC (1995) Association of Official Analytical Chemists. Official Methods of Analysis. (16th edn.) Washington DC, USA. recorded values of 0.04-1.05, 1.05-3.26 and 0.07-4.5 $\mathrm{QE} / 100 \mathrm{~g}$ quercetin in cabbage, broccoli, and kale respectively. Catechin contents were lowest, in A.dubius $(3.75+0.39 \mathrm{CE} / 100 \mathrm{~g})$ and $A$. hypochondriacus $(3.63+0.2$ $\mathrm{CE} / 100 \mathrm{~g})$. Phytochemicals such as phenolic compounds and flavonoids possess strong antioxidant properties and have been implicated in the prevention of cancer and cardiovascular disease, diabetes and aging (Hertog et al 1992, Adeoye et al 2005). Intake of phytochemicals such as flavonoids reduces the risk of coronary artery disease (Hertog et al 1992) Flavonoids have also been reported to have medicinal properties such as antimicrobial and antioxidant properties (Stephen et al., 2009).

highest total phenols, quercetin, and catechin. Consumption of this species could potentially reduce the risk of chronic diseases which are so rampant in Kenya today. The data generated from this study provides an important insight on the differences in nutrition content of various amaranth species. This is important in identification of the best sources of various nutrients especially in nutritional interventions. Therefore the production, utilization and conservation of amaranth through educational programs and market linkages to communities should be promoted.

sponsoring and facilitating the completion of this research work at Jomo Kenyatta University of Agriculture and Technology.

Bhagwat S. David B. Haytowitz and Joanne M. Holden, (2011) USDA Database for the flavonoid content of selected foods.U.S.

FAO. (2004). Tables of Food Composition for Use in Africa.FAO and U.S Department of Health.www.fao.org/docrep/003/X6877E/X6877 E01.htm.

GoK (2004). Strategy for revitalizing Agriculture 20042014: Ministry of Agriculture and the Ministry of Livestock and Fisheries Development. Nairobi, Kenya.

Gqaza B. M., Collise Njume, Nomalungelo I Goduka, and Grace George The Proximate Composition 
of S. Nigrum Plant-Leaves Consumed in the Eastern Cape Province of South Africa South Africa

Hanif R, lqbal Z, Iqbal M, Hanif S and Rasheed M (2006) use of vegetables as nutritional food; Role in human health Journal of agricultural and biological science vol.1, no.1, www.arpnjournals.com

Hertog, M.G.L., Hollman, P.C.H., Katan, M.B. (1992). Content of potentially anticarcinogenic flavonoids of 28 vegetables and 9 fruits commonly consumed in the Netherlands. Journal of Agriculture. Food Chemisty.40: 2379

IPGRI (2003). Rediscovering a forgotten treasure. IPGRI Public Awareness Forum. Nairobi, Kenya. IPGRI/National Museums of Kenya. http//ipgripa.grinfo.net/index.php?itemid $=101$

Ishida, H., Suzuno, H., Sugiyama, N., Innami, S., Todokoro, T. and Maekawa, A. (2000) Nutritional evaluation of chemical component of leaves stalks and stems of sweet potatoes (Ipomea batatas poir). Food Chemistry.68: 359367.

Itúrbide, G.A., and Gispert, M. (1994).Grain amaranths (Amaranthus spp.). In: Neglected crops: 1492 from a different perspective. J.E. Hernándo Bermejo and León, J. (eds). Plant production and Protection series No. 26. FAO, Rome, Italy. p. 93-101

Jaarsvelda P.V, Mieke Fabera, Ina van Heerdenb, Friede Wenholdc, Willem Jansen van Rensburgd, Wim van Averbekee 2013. Nutrient content of eight African leafy vegetables and their potential contribution to dietary reference intakes Journal of food composition and analysis pg 77-84.

Jacob Alemu (2005), The Africa executive magazine. A plant full of medicinal values http://www.africanexecutive.com/modules/maga zine/articles.php?article $=331$

Kwenin, W.K.J.; Wolli, M. and B.M. Dzomeku (2011),,Assessing the nutritional value of some African indigenous green Leafy Vegetables in Ghana (2011), Journal of Animal \& Plant Sciences, 2011. Vol. 10, Issue 2: 1300- 1305. http://www.biosciences.elewa.org/JAPS; ISSN 2071

Mibei E. K (2011) Nutritional, Phytochemical and In Vitro Antimicrobial screening of some Indigenous Leafy Vegetables
Nana F. W, Hilou A, Millogo, J. F. Nacoulma O. G. (2012) Phytochemical Composition, Antioxidant and Xanthine Oxidase Inhibitory Activities of Amaranthus cruentus L. and Amaranthus hybridus L. Extracts Pharmaceuticals www.mdpi.com/journal/pharmaceuticals

National Academy of Sciences (2001). Dietary Reference Intakes for Vitamin A, Vitamin K, Arsenic, Boron, Chromium, Copper, lodine, Iron, Manganese, Molybdenum, Nickel, Silicon, Vanadium, and Zinc

National Research Council. (1984). Amaranth: Modern prospects for an ancient crop. National Academy Press. Washington, USA. $74 \mathrm{p}$.

Onyango C. M. (2010) Preharvest and Postharvest Factors Affecting Yield and Nutrient Contents of Vegetable Amaranth (Var. Amaranthus hypochondriacus) Wageningen, (PhD Thesis)

Onyango, M.C., and Imungi, J.K. (2007). Postharvest handling and characteristics of fresh-cut traditional vegetables sold in Nairobi-Kenya. In: Crop research, technology dissemination and adoption to increase food supply, reducing hunger and poverty in Africa. 8th African Crop Science Conference Proceedings, Part 3 and 4 , 27-31, El-Minia, Egypt.

Onyango, M.C., Shibairo, S.I., Imungi, J.K., and Harbinson, J. (2008). The physico-chemical characteristics and some nutritional values of vegetable amaranth sold in Nairobi-Kenya. Ecol. Food Nutrition. 47: 382-398

Raja, TK, Othman, OC and Bahemuka, TE. (1997). Levels of Crude Protein and some Inorganic Elements in Selected Green Vegetables of Dar es Salaam. Journal of Food Science and Technology 34(5):419-422

Saunders, R.M., and Becker, R. (1984).Amaranthus: A potential food and feed source. Advances in cereal science and technology. Amer. Assn. Cereal Chem 6: 357-396.

Spanos, G.A. and Wrolstad, R.E. (1990) Influence of processing and storage on the phenolic composition of Thompson seedless grape juice. Journal of Agriculture and Food Chemistry. 38: 1565-1571.

Srivastava (2011) Nutritional quality of some cultivated and wild species of amaranthus $L$. international Journal of pharmaceutical sciences and research Vol. 2(12): www.ijpsr.com 3152 
The council for responsible nutrition (2002). The benefits of nutritional supplements.

Tucker, J.B. (1986). Amaranth: the once and future crop. Bioscience, 36:9-13, 59-60

Uusiku, N.P., Oelofse, A, Duodu K.G., Bester M.J. \& Faber, M. (2010). Nutritional value of leafy vegetables of sub-Saharan Africa and their potential contribution to human health: A review. Journal of Food Composition and Analysis, 23; $499-509$.

Wambugu P.W. and Muthamia Z.K (2009).The state of plant genetic resources for food and agriculture in Kenya: KARI, National Gene bank of Kenya 